\title{
REVIEW
}

\section{Detection of misfolded protein aggregates from a clinical perspective}

\author{
Øyvind Strømland ${ }^{\S}$, Martin Jakubec ${ }^{\S}$, Samuel Furse, Øyvind Halskau* \\ Department of Molecular Biology, University of Bergen, Bergen, Norway
}

\section{ARTICLE INFO}

\section{Article history:}

Received: December 24, 2015

Revised: March 22, 2016

Accepted: March 22, 2016

Published online: March 22, 2016

\section{Keywords:}

protein misfolding

Alzheimer's

Parkinson's

neurodegenerative disease

oligomer toxicity

membrane porosity

lipid

antibody

lectin

mass spectrometry

\begin{abstract}
Neurodegenerative Protein Misfolding Diseases (PMDs), such as Alzheimer’s (AD), Parkinson’s (PD) and prion diseases, are generally difficult to diagnose before irreversible damage to the central nervous system damage has occurred. Detection of the misfolded proteins that ultimately lead to these conditions offers a means for providing early detection and diagnosis of this class of disease. In this review, we discuss recent developments surrounding protein misfolding diseases with emphasis on the cytotoxic oligomers implicated in their aetiology. We also discuss the relationship of misfolded proteins with biological membranes. Finally, we discuss how far techniques for providing early diagnoses for PMDs have advanced and describe promising clinical approaches. We conclude that antibodies with specificity towards oligomeric species of $\mathrm{AD}$ and $\mathrm{PD}$ and lectins with specificity for particular glycosylation, show promise. However, it is not clear which approach may yield a reliable clinical test first.

Relevance for patients: Individuals suffering from protein misfolding diseases will likely benefit form earlier, less- or even non-invasive diagnosis techniques. The current state and possible future directions for these are subject of this review.
\end{abstract}

\section{Introduction}

The oligomerization and then fibrillation of misfolded proteins is a common feature of a large group of diseases referred to as protein misfolding diseases (PMDs). A subset of these diseases is known as neurodegenerative because they cause irreversible damage to the central nervous system (CNS). Several different proteins may precipitate the clinical symptoms of these conditions, several parts of the CNS may be damaged and the mechanism of the condition varies (Table 1). The best known examples of neurodegenerative PMDs include Parkin- son's [1,2] and Alzheimer's [2-4] diseases (PD and AD, respectively). Prionic diseases are less common and less predictable than the others but their immediate clinical impact can be more dramatic $[5,6]$. There are also a number of hereditary conditions also counted among the neurodegenerative PMDs, the most well- known of these being Huntington's Disease (HD) [7]. While the exact nature and relevance of protein misfolding is sometimes debated, for instance the relevance and nature of Huntingtin (Htt) aggregation in HD [8,9], there is agreement that misfolded, mis-aggregated or wrongly processed proteins are the unifying feature of these conditions

\section{List of abbreviations}

Alzheimer's Disease, AD; Amyloid Precursor Protein, APP; Beta-Amyloid, A $\beta$; Bovine Spongiform Encephalopathy, BSE; Creutzfeldt-Jakob Disease, CJD; Central Nervous System, CNS; Immunofluorescence, IF; Immunoprecipitation, IP; Enzyme Linked Immunosorbent Assay, ELISA; Huntingtin, Htt; Huntington's Disease, HD; Immunohistochemistry, IHC; Luminescent Conjugated Oligothiophenes, LCOs; Parkinson's Disease, PD; Prion Protein Cellular, PrPC; Prion Protein Scrapie-associated, PrPSc; Protein Misfolding Disease, PMD; $\alpha$-Synuclein, $\alpha$-Syn; Western Blot, WB.

§These authors contributed equally to this work.

*Corresponding author:

Øyvind Halskau

Department of Molecular Biology, University of Bergen, Thormøhlensgate 55, 5008, Bergen, Norway.

Tel: 004755584563

E-mail: oyvind.halskau@uib.no 
Table 1. Neurodegenerative protein misfolding diseases

\begin{tabular}{|c|c|c|c|}
\hline Protein Misfolding Disease & Aggregating protein(s) & Aetiology & Clinical Manifestation \\
\hline $\mathrm{AD}$ & $\mathrm{A} \beta$, Tau [128] & $\begin{array}{l}\text { Acquired; age, } \\
\text { gene variants in- } \\
\text { crease risk, see } \\
\text { also familial forms }\end{array}$ & $\begin{array}{l}\text { Dementia, language difficulties, execu- } \\
\text { tive dysfunction, depression, hallucina- } \\
\text { tions, delusions, agitation, apathy, disin- } \\
\text { hibition [128] }\end{array}$ \\
\hline
\end{tabular}

Cerebral amyloid angiopathy

A $\beta$, BRI2, Cystatin C, gelsolin, PrPSc, Transthyrin [130]

PD

$\alpha-S y n$, Tau [131,132]

Frontotemporal lobar degeneration

Huntington's disease

Htt [135]

Familial British dementia, and Familial Danish dementia

CADASIL, Cerebral autosomal dominant arteriopathy with subcortical infarcts and leukoencephalopathy

Alexander disease

\section{GFAP [140]}

Familial encephalopathy with neuroserpin inclusion bodies Kuru

Neuroserpin [142]

$\operatorname{PrP}[144]$

Creutzfeldt-Jakob disease

PrP [145]

Gerst-

mann-Straussler-Scheinker syndrome

Fatal familial insomnia $\operatorname{PrP}[144]$

Progressive supranuclear palsy

Tau [149]

Chronic traumatic encephalopathy

Tau, TDP-43 [151]
Acquired; age, fa- Cerebral haemorrhage, ischemic lesions, milial factors and progressive dementia [130] familial subtypes types identified

Acquired; head trauma, specific gene variants known to increase risk

REM sleep behaviour disorder, Excessive daytime sleepiness, hyposmia, depression, bradykinesia, rigidity, tremors, mild cognitive impairment, dyskinesia, dysphagia, postural instability, freezing of gait, orthostatic hypotension [131]

Personality changes, behavioural disinhibition, apathy, progressive aphasia [53]

Congenital, monogenic

Congenital, monogenic

Congenital, monogenic [139]

Mild psychotic and behavioural symptoms, progressive chorea, rigidity, dementia, dystonia, bradykinesia [135]

Progressive cognitive impairment, spastic tetraparesis, cerebellar ataxa [137]

Mood disturbances, apathy, subcortical ischemic events, migraine with aura, cognitive impairment [138]

Sporadic; gene variants increase risk

Macrocephaly, frontal leukodystrophy, palatal tremors, dysphagia, cognitive delays, seizures [140]

Congenital, Dementia, epileptic, seizures, progresmonogenic [143] sive myoclonus, dysarthria [142]

Acquired; transmitted

Acquired; transmitted

Major genetic contributions [147]

Cerebellar ataxia, choreifrom, athetoid movements, nystagmus, dysphasia [144]

Dementia, myoclonus, visual or cerebellar disturbance, akinetic mutism, pyramidal or extrapyramidal signs [146]

Cerebellar ataxia, gait abnormalities, dementia, dysarthria, ocular dysmetria, myoclonus, spastic paraparesis, parkinsonism, hyporeflexia or areflexia in lower extremities [144]

Congenital, monogenic [148] Insomnia, myoclonus, ataxia, dysarthria, dysphagia, pyramidal signs, autonomic hyperactivation [144]

Acquired; head Progressive axial rigidity, vertical gaze trauma [150] palsy, dysarthria, dysphagia [149]

Acquired; head trauma [152] erograde amnesia, executive dysfunc-
Learning and memory impairment, anttion, depression, apathy, irritability, suicidality, loss of impulse control, dementia, PD, dysarthria [151]

Global dementia, progressive aphasia, gaze palsy, parkinsonism, progressive supranuclear palsy [153]
Pathogenic mechanism tangles observed. Selective loss of cholinergic neurones, loss of synapses and neurones in the cerebral cortex, atrophy of frontal cortex cingulate gyrus, temporal lobe and parietal lobe [129]

Progressive deposition of amyloid protein in cerebral blood vessel walls leading to degenerative vascular changes [130]

Manifestation of Lewy bodies enriched in $\alpha$-Syn. Loss of dopaminergic neurons in the substantia nigra, Neuroinflammation with reactive gliosis and microgliosis [131]

Neuronal loss, gliosis, microvacular changes of frontal lobes, anterior temporal lobes, anterior cingulate cortex and insular cortex [133]

Gross striatal atrophy, neuronal loss in neocortex, cerebellum, hippocampus, substantia nigra, and brainstem nuclei [135]

Amyloid angiopathy and neurofibrillary tangles (NFTs) in the hippocampus [136]

Degeneration of smooth muscle cells in blood vessels [138]

Demyelination, Rosenthal fibres in astrocytes [141]

Poorly understood, encephalopathy with neuroserpin inclusion bodies [142]

Spongiform change, neuronal loss, astrocytic microgliosis, kuru plaques [144]

Spongiform change, neuronal loss, gliosis [145]

Amyloid plaques, severe to absent spongiform changes, neuronal loss, astrocyte microgliosis, variable neurofibrillary tangles [144]

Neuronal loss, astrogliosis, hypometabolism in the thalamus and cingulate cortex [144]

Neuronal loss, gliosis, neurofibrillary tangles affecting brainstem, basal ganglia, diencephalon [149]

Atrophy of frontal and temporal cortices and medial temporal lobe, atrophy of the thalamus, hypothalamus and mammillary bodies. Thinning of the corpus callosum, pallor of the substantia nigra and locus coeruleus, cavum septum pellucidum [151]

Poorly understood, neurofibrillary tangles are found in the brain [153]
Lytico-Bodig disease $\quad$ Tau [153] Acquired 


\begin{tabular}{|c|c|c|c|c|}
\hline Protein Misfolding Disease & Aggregating protein(s) & Aetiology & Clinical Manifestation & Pathogenic mechanism \\
\hline Meningioangiomatosis & Tau [154] & Acquired & $\begin{array}{l}\text { Epileptic seizures, haemorrhagic stroke, } \\
\text { anginoma, status epilepticus, general- } \\
\text { ized tonic-clonic seizures [155] }\end{array}$ & $\begin{array}{l}\text { Focal lesion of the leptomeninges and } \\
\text { underlying cerebral cortex [155] }\end{array}$ \\
\hline $\begin{array}{l}\text { Neuronal Ceroid } \\
\text { Lipofuscinosis }\end{array}$ & $\begin{array}{l}\text { ATP synthase subunit c, } \\
\text { saposin A, saposin D } \\
\text { [156] }\end{array}$ & $\begin{array}{l}\text { Congenital, mon- } \\
\text { ogenic, subtypes } \\
\text { exists [157] }\end{array}$ & $\begin{array}{l}\text { Hypotonia, myoclonic jerks, generalized } \\
\text { epileptic seizures, developmental regre- } \\
\text { ssion, optic atrophy, macular degenera- } \\
\text { tion, spastic tetraplegia, blindness, severe } \\
\text { and constant microcephaly, and phar- } \\
\text { maco-resistant epileptic seizures, myoclo- } \\
\text { nia, ataxia, extrapyramidal signs [156] }\end{array}$ & $\begin{array}{l}\text { Cerebellar and cortical atrophy, loss of } \\
\text { pyramidal neurons and Purkinje cells, } \\
\text { reactive astrogliosis [156] }\end{array}$ \\
\hline Argyrophilic grain disease & Tau [158] & $\begin{array}{l}\text { Acquired; old age } \\
\text { [158] }\end{array}$ & $\begin{array}{l}\text { Cognitive decline, dementia, mood } \\
\text { imbalance, personality changes, behav- } \\
\text { ioural abnormalities [158] }\end{array}$ & $\begin{array}{l}\text { Argyrophilic grains in trans entorhinal } \\
\text { cortex, entorhinal cortex, hippocampus, } \\
\text { presubiculum, temporal cortex, orbito- } \\
\text { frontal cortex, insular cortex, and } \\
\text { amygdala[158] }\end{array}$ \\
\hline
\end{tabular}

[10]. Full recovery has not yet been observed in any patient after damage to nerve tissue has begun. Clear and early diagnosis of these conditions is therefore essential for informing sufferers about their condition, managing the condition where this is possible and giving appropriate palliative care. Theoretically, early diagnosis might help guide choice of treatment in cases where effective options are available.

The desire for both prompt diagnosis and improved medical treatments has thus encouraged research into misfolded protein aggregates and their relative PMDs. Diligent research has identified and characterised many of the individual proteins involved in these conditions. For example, $\beta$-amyloid (A $\beta$ ) [11] and Tau in AD [12], $\alpha$-Synuclein ( $\alpha$-Syn) in PD [13,14] and Htt in HD [7] are now largely accepted to have key roles in these diseases (For other protein involvement in given diseases, see Table 1). Despite this, tests for diagnostic compounds (biomarkers) are not in routine use for identifying any of the non-hereditary PMDs. For instance, when assessing patients for $\mathrm{AD}$, clinicians have to rely on an imaging or visual data regarding symptoms and standardized tests that are sometimes combined with MRI [7]. Biopsies for detecting changes in the CNS are considered invasive procedures that are generally unsuitable for elderly patients, and thus they are usually only used for verification of the diagnosis post mortem [15]. Importantly, tissue damage precedes the formation of the characteristic insoluble fibrils that are detected in brains of AD sufferers. Such fibrils are not cytotoxic and their formation correlates only poorly with disease progression [16]. This suggests that other agents, such as oligomers of the same misfolded proteins as the fibrils, are responsible.

The common features of neurodegenerative PMDs, in which only one or two proteins appear to be defective, or at least the processing of which is defective, is an attractive target for translational research aiming to detect the condition in its early stages. One possible diagnostic tool is therefore a detection system for the activity of proteases that are also involved in the progression of the disease, such as caspase-8 activation in the case of PD [17] and $\beta$ - and $\gamma$-secretase in $\operatorname{AD}[18,19]$. One problem with this approach is that such processes do not have a unique association with the diseases in question. Another approach would be to focus on the individual misfolded proteins at an early stage, rather than the insoluble plaques and reduction in tissue volume associated with advanced stages. Sensitive tools are required for the early detection of conditions where the underlying biochemical changes may be small or difficult to resolve. For example, only minute quantities of transmissible misfolded prions are required to precipitate Creutzfeldt-Jakob Disease (CJD) in humans [6], bovine spongiform encephalopathy (BSE) and scrapie in sheep [20]. Nor is it necessarily straightforward to detect changes in protein folding, aggregation or processing in bodily fluids. Despite these challenges, methods for monitoring such changes in the relevant proteins of PMDs are of clinical interest. In this review, we explore recent advances in translational research focused on detecting misfolded proteins in the context of early pre-fibril misfolding. We discuss these advances from both a research and a clinical perspective. We conclude with a forward-looking view on possible research directions.

\section{Protein misfolding, oligomerisation and toxicity}

Proteins pass through a fundamental process called folding in order to obtain their functional structure [21-23]. Folding is usually spontaneous under physiological conditions, and occurs at rates that depend upon the protein's size [24]. This process takes a couple of hundred milliseconds for most proteins [25]. Early steps in protein folding include the clustering of hydrophobic amino acids and the expulsion of water, the subsequent compaction of the polypeptide chain and consolidation of secondary structure. Then, a re-ordering and finetuning of the structural elements takes place to afford the final tertiary structure. The folding process needs to make particular intra-fold contacts both in its early and late stages. All these steps are affected by the protein's environment. Factors that affect the outcome of a folding process and aggregation behaviour include solvent conditions, the presence or absence of cofactors and metal cations [26], chaperones or other dissolved factors, crowding from other proteins or macromolecular aggregates, spatial organization and post-translational modifica- 
tion (reviews [27,28]). The fact that folding is influenced by many factors is also reflected in the cell biology of the PMDs. The state of the prion protein associated with CJD is both translocated into the ER and glycosylated differently than its non-pathogenic counterparts [29,30]. Copper and zinc ions are implicated in both $\mathrm{AD}$ and $\mathrm{PD}$, as there is evidence that they influence disease onset and progress in animal models and have been highlighted in clinical studies [31]. It is not entirely clear whether $\mathrm{Cu}^{2+}$ and $\mathrm{Zn}^{2+}$ are only involved in the misfolding of proteins or also in the aggregation of those proteins into fibrils [32].

Amyloid fibrils are widely recognized as a result of protein misfolding and have been observed both in vitro and in vivo. They are repetitive sheets in which monomers are joined by hydrogen bonds across $\beta$-strands. The long sheets are slightly twisted, with varying dimensions and crossover distances depending on the polypeptide involved. Cryo-electron microscopy has indicated that in $A \beta$ the fibril is approximately $4 \mathrm{~nm}$ and $11 \mathrm{~nm}$ at the narrowest and widest points respectively and has a twist crossover distance that has a mean of about $100 \mathrm{~nm}$. Comparative work on fibril morphology from $\mathrm{A} \beta$ and $\alpha$-Syn indicates that they are similar, but with a degree of polymorphism [33-35]. A considerable range of proteins and protein fragments can form fibrils, suggesting that the barrier to formation of these states is more likely to rest with time and physico-chemical conditions than amino acid sequence.

Importantly, the extent of fibril formation does not appear to correlate with disease progression and naturally occurring mutants associated with the early onset of PMDs do not produce more fibrils [16]. For these reasons, attention has been given to the aggregates preceding fibril formation. It has been proposed recently that the toxic oligomers are, just like fibrils, a general phenomenon that forms relatively independently of protein sequence [36]. The oligomerisation of other proteins such as calcitonin [37], $\alpha$-Syn [38], Syrian hamster prion protein [39], GAP-43 and BASP1 [40] is consistent with this. The oligomers have since been shown to display significant toxicity-related effects relative both to monomers, fibrils and proto-fibrils [41,42]. Furthermore, rates of their formation are better able to account for disease-promoting mutations $[16,37,42,43]$. It has also been suggested that their toxicity is linked to membrane damage through a pore-like action [44] and a range of pre-fibrillar oligomeric structures from a several proteins, including $\mathrm{A} \beta$, Htt, prion proteins, and $\alpha$-Syn, has since been investigated in this context $[39,43,45,46]$.

\section{Misfolded proteins and the lipid profile of the membrane}

It is well established that membrane or peripheral proteins may affect membranes and vice versa (review [47]). The lipid-dependent, differential processing of APP to $\mathrm{A} \beta$ is one particularly relevant example of this [48]. Moreover, PMD proteins and notably their oligomeric states have considerable effects on membrane integrity. Furthermore, tissue deposits of amyloid fibrils contain lipids [49]. Imaging studies on pre- fibrillar oligomers reveal a range of structures, some of which may have a pore-like morphology (review [50]). These are referred to as amyloid pores or sometimes annular oligomers [51]. Whether such oligomers will go on to form mature amyloid fibrils exclusively is not clear, as there exists reports in which pore-like oligomers do not appear to undergo fibrillation [52]. Certain drugs can arrest fibril but not oligomer formation [53]. Even though the presence of non-fibrillar, porelike oligomers correlates better with toxicity and disease-promoting mutants than fibrils, their properties, mechanism of action and what promotes or suppresses their formation remains poorly understood.

Two competing hypotheses that may explain the effect of oligomers on the membrane are being researched at the moment. The first suggests that oligomer toxicity is a direct result of pore formation. Examples of oligomers that may effect pore formation include those generated by islet amyloid polypeptide [54-57], poly-glutamine [58], transthyretin [59], prion protein fragment [60], $\mathrm{A} \beta$ [61], $\beta 2$-microglobulin [62] and serum amyloid A [63]. Porosity was indicated by ionic flux across reconstituted membranes, which compromises cellular homeostasis and membrane potential [61]. The second hypothesis being tested at present is that the oligomers cause membrane thinning rather than leakage, through a distinct pore [42,64,65]. In this scenario, leakage through the membrane is independent of the pore-like aggregate morphologies and can take place through any area of the membrane that is sufficiently perturbed by these aggregates. Membrane thinning involves the increase of area per lipid and intercalation of polypeptides and water molecules between head groups in order to avoid energetically costly vacuums in the lateral lipid packing. This has the effect of lowering the dielectric barrier and allowing ion leakage through the membrane $[10,66]$.

Experimental determination of leakage through a pore formation or through thinning of the membrane is not straightforward. Regardless of the particular mechanism, the oligomers convey toxicity by perturbing the integrity of the membrane. However, the membranes may in turn affect the oligomers, too. Aggregating, oligomeric peptides have been shown to have preferential binding to particular membrane components, in particular sphingolipids and cholesterol. Sphingolipids and cholesterol are found in patches termed the liquid ordered phase that are often referred to as lipid rafts [67], though controversy about this link exists [68]. Glycosphingolipids and gangliosides have affinity for the $\mathrm{A} \beta$ peptide in $\mathrm{AD}$ and $\alpha$-Syn interacts with $\mathrm{GM}_{1}$ and $\mathrm{GM}_{3}$ gangliosides [69-74]. PrP has been associated with sphingolipid signalling platforms and bind to sphingomyelin, GalCer, $\mathrm{GM}_{1}$ and $\mathrm{GM}_{2}$ $[70,75,76]$. A strong interaction with sphingolipids may reflect the amount of amyloidogenic protein found in possible lipid raft areas of the extracellular leaflet of the plasma membrane [49]. Amyloidogenic proteins such as $\alpha$-Syn also interact more strongly with anionic lipids phosphatidylglycerol and phosphatidylserine, found mainly in the cytoplasmic leaf [45,77-79]. Model systems comprising the anionic lipids cardiolipin, phosphatidic acid or phosphatidylglycerol leak more 
on contact with oligomers [45].

The role of cholesterol in membrane behaviour has been researched in some depth [80-88] but its role in oligomer formation and amyloidogenesis remains disputed and controversial [89]. Cholesterol has been shown to bind to $A \beta$ proto-fibrils, but how these interactions influence oligomerization and later fibrillogenesis remains unclear [90-92]. There is evidence that cholesterol can have a stabilizing effect on membrane permeability as it reduces the leakage induced by $\alpha$-Syn [46]. The role of cholesterol in the proteolysis of APP to give $\mathrm{A} \beta$ is better understood. Proteolysis of APP is inhibited by the group of cholesterol synthesis inhibitors known as statins [93,94]. In PD a depletion of cholesterol leads to a decreased level of $\alpha$-Syn in membrane fractions in neuronal cell cultures and mouse brains [95]. Inhibition of cholesterol synthesis also reduces the levels of $\alpha$-Syn in membranes, but the opposite applies to cholesterol supplementation in neuronal cells [96]. It has also been suggested that oxidised cholesterol accelerates aggregation of $\alpha$-Syn [97].

This evidence may be at odds with the observation that cholesterol protects artificial membranes against oligomerinduced leakage [46] as it fails to provide a direct connection to the proposed toxicity mechanism. Polyunsaturated fatty acids may have an inhibitory role in oligomerization. The presence of docosahexaenoic acid (DHA) suppresses the toxicity of $\mathrm{A} \beta$ towards SH-SY5Y cells by interfering with its aggregation $[98,99]$, and appears to have a neuro-protective role in murine models for AD [100]. However, DHA can also affect the progress of some cells through the cell cycle [101]. The notion that saturation levels of the fatty acid residues (FARs) of phospholipids in membranes play a role in modulating the rate of oligomerization agrees with measurements from model systems that indicate that saturated fatty acid residues lower the energetic barrier to aggregation [102].

Further work is required to understand the complexities of the relationship between membrane components and protein misfolding and oligomerization. It is possible that certain lipids or other membrane components may be used as diagnostic compounds for more reliable early-stage detection of neurodegenerative PMDs in combination with detection of the oligomeric proteins, should the links between lipid species and oligomerization prove robust.

\section{Clinical detection of protein aggregates}

There is no single rigorous assay for diagnosis of any PMD. The mounting evidence for the involvement of toxic oligomers in neurodegeneration confers an increasing importance on detection methods for basic and translational research, and in clinical practice. As a result, great research effort is being focused on developing clinical methods for detecting the main pathological unit of AD. At present, diagnosing AD includes a test of cognitive impairment (The Mini Mental State Exam or Folstein test), in some cases supplemented by CSF assays for phosphorylated tau and $\mathrm{A} \beta$, MRI for brain volume and PET scans for $A \beta$ plaques (or glucose metabolism) in the brain
[103].

An overview of methods for clinical detection of protein aggregates is shown in Table 2. Generally, approaches for the identification of protein aggregates can be divided into three classes of method: (i) visualization of protein aggregates in biopsies, (ii) monitoring of marker peptide in bodily fluids, and (iii) visualization of protein aggregates in vivo using imaging techniques. Most of the methods discussed here concern $\mathrm{A} \beta$ peptide detection in $\mathrm{AD}$, as this field has advanced the furthest. The majority of approaches rely on antibodies to confer specificity to the detection, whether it occurs in biopsies, bio-fluids or in vivo. A considerable number of different antibodies have been developed in the last two decades, many of which have at least some degree of specificity towards the proteins and aggregation-states involved in neurodegenerative PMDs. An overview of some of their properties is shown in Table 3a.

The visualization of amyloid plaques in samples from biopsies is a well-established means for qualitative detection of mature fibrils. There are several standard stains, such as Congo red and fluorescent thioflavins [104], as well as immunohistology stains based on antibodies [105]. There have been several recent advances in the development of fluorescent probes based on luminescent conjugated oligothiophenes (LCOs) which can be used for investigating the nature of these protein deposits $[106,107]$. LCOs are able to illuminate more protein deposit plaques than other fluorophores [108]. Moreover, the emission spectra of LCOs are dependent on the type of predominant peptide present. This makes it possible to distinguish e.g. AD-associated aggregates from other types of aggregates [109,110]. Another new and promising way of detecting of amyloid plaques is the discovery of photo-induced electron transfer probes that can be used to detect $A \beta$ aggregates without the need of a washing step [111]. These recently-developed fluorescent probes represent a new opportunity in direct and sensitive identification of protein aggregates, especially in complex biological environments.

The second class of methods for the detection of proteins and their aggregates detects molecules in bio-fluid samples, avoiding the need for biopsies. These clinical methods rely on the detection of marker peptides in cerebrospinal fluid (CSF). For instance, detection of $\mathrm{A} \beta$ or tau protein in $\mathrm{AD}$ has been shown to have predictive power over which individuals will go on to develop the disease [112]. Detection of the relevant molecular species in CSF is relatively straightforward and a broad array of methods exists for its detection. It is possible to detect and quantify tau peptides in the lower $\mathrm{ng} / \mathrm{mL}$ range using mass spectrometry on samples acquired directly from the CNS [12], although this not in routine clinical use yet.

A more common method is the use of enzyme-linked immuno-sorbent assays (ELISA) [113]. For example, antibodies 2G3 and 21F12 are used for the detection of C-terminal amino acids of $\mathrm{A} \beta$ peptides $1-40$ and 1-42, respectively, in diagnosis of AD [114]. The same peptides can be detected by new electrochemical detection immuno-sensors. These biosensors are based on immobilization of antibodies on gold nanostructured 
Table 2. Clinical detection of protein aggregates

\begin{tabular}{|c|c|c|}
\hline Proteopathy & $\begin{array}{l}\text { Misfolding/oligomerizing } \\
\text { protein }\end{array}$ & Current methods for clinical detection \\
\hline \multirow[t]{4}{*}{$\mathrm{AD}$} & \multirow[t]{2}{*}{ A $\beta$ peptide } & $\begin{array}{l}\text { Decrease of marker peptide concentration in CSF, detected by ELISA, immu- } \\
\text { no-sensors }[112,113,115]\end{array}$ \\
\hline & & $\begin{array}{l}\text { Fluorescent labelling of biotic samples with luminescent conjugated oligothio- } \\
\text { phenes [106,107,109-111] }\end{array}$ \\
\hline & \multirow[t]{2}{*}{ Tau protein } & $\begin{array}{l}\text { Ratio of phosphorylated Tau in position } 396 \text { and } 404 \text { in CSF could discriminate } \\
\text { AD from other dementia; Identification by ELISA [161] }\end{array}$ \\
\hline & & $\begin{array}{l}\text { Identification of phosphorylated biomarkers pTau181, pTau199 and pTau231 in } \\
\text { CSF by immunoassays [162-167] }\end{array}$ \\
\hline Cerebral amyloid angiopathy & A $\beta$ peptide & $\begin{array}{l}\text { Early phase PET imaging of cerebral fibrillary } \beta \text {-amyloid with 11C-Pittsburgh } \\
\text { compound B as a PET ligand [168-170] }\end{array}$ \\
\hline PD & $\alpha-S y n$ & Detection of $\alpha$-Syn oligomers in human plasma or red cells by ELISA $[175,176]$ \\
\hline Huntington's Disease & $\mathrm{Htt}$ & $\begin{array}{l}\text { Loss of brain volume observed by MRI with combination of genetic test - iden- } \\
\text { tification of abnormal CAG expansion in exon1 of htt gene [177-179] }\end{array}$ \\
\hline Variant Creutzfeldt-Jakob disease & Prion protein $\operatorname{PrP}$ & Whole blood immunoassay [180-182] \\
\hline Other prion diseases: & Prion protein $\operatorname{PrP}$ & Conformation dependent immunoassays in biopsy samples[183,184] \\
\hline
\end{tabular}

Gerstmann-Sträussler-Scheinker disease, fatal

familial insomnia, kuru, Creutzfeldt-Jakob Disease

screen-printed electrodes with cyclic voltammetry detection [115], or with difference pulse voltammetry detection with immobilization on gelsolin coated electrodes that selectively binds $\mathrm{A} \beta$ peptides [116]. Another interesting approach combines ELISA and surface plasmon resonance to provide greatly enhanced detection, using gold nano-particles conjugated with antibodies [117]. The role of the nano-particles in this assay is to increase the change in refractive index response that each immobilized molecule produces. This provides detection limits as low as single molecules. This technique is also designed to handle precipitates as part of the detection assay, which may be an advantage when working with oligomerization states.

The last group of methods allow direct observation of amyloid plaques in vivo. This direct observation is appealing for clinical use, but is not yet practiced routinely. Methods like magnetic resonance imaging (MRI), positron emission tomography (PET) [118] and diffusion-tensor imaging [119,120] are being developed for direct diagnosis of amyloid plaques based on visual inspection of advanced imaging output. However, all of these methods are based only on qualitative approaches and rely on detecting visible changes in the CNS. There has been some work on quantification of amyloid loads based on PET image analysis but with very limited results [118,121]. More recent advances in MRI are based mainly on the use of particles that allow localization of particular plaques. For example it is possible to use curcumin-conjugated magnetic nano- particles [122] or hollow manganese oxide nano-particles conjugated with a particular antibody [123]. Both of these nanoparticle methods increase the specificity and sensitivity of the techniques towards the protein aggregates. However, these approaches are not in routine use and may not satisfy the need for diagnosis before irreparable damage to tissue has occurred.

\section{Concluding remarks and future perspectives}

The methods available for detecting proteins associated with neurodegenerative PMDs shows some promise for clinical use. However, many of these methods make no distinction between monomers or oligomers. Thus, the preparation of diagnostic tools that monitor the advancement of oligomerization at an early stage is still under development.

Antibodies are one of the most well established and still promising directions for developing diagnostic tools. Antibodies with ligand conformation sensitivity could be used to build one or more specific standardized clinical ELISA assays for detection of misfolded oligomers. The reliability of such immuno-based approaches is limited by the quality of the antibody involved. Notably, antibody-based detection of the misfolded oligomers, for instance Tau and $\mathrm{A} \beta$, has advanced in recent years (see Table $3 a$ ), indicating that standard assays based on immunology may indeed be made sensitive to oligo- 
meric forms. Ensuring that there is a low limit of detection in a complex bio-fluid is also a concern, for ensuring early diagnosis.

Another approach could be the use of native mass spectrometry for detecting protein aggregates. It is a technique which, in contrast to other types of mass spectrometry, can detect non-covalent interactions between proteins [124]. This technique is also able to detect protein complexes across a wide range of molecular masses and handles heterogeneous samples well. All these features are attractive when aiming to detect oligomers in complicated samples such as bio-fluids. Native mass spectrometry has been used successfully to investigate the assembly of virus capsid, directly from crudely purified culture extract [125]. In principle, it is also possible to detect the oligomers discussed above. An overview of recent, promising use of mass spectroscopy in neurodegenerative PMDs can be found in Table 3c.

The detection of protein glycosylation may be a means for detecting prionic diseases at an early stage (See Table 3b for references). This approach relies upon detailed knowledge of the glycosylation chemistry involved. Although mass spectrometry may be helpful in identifying prion protein glycosylation species, the most promising tool at present are lectins. These are saccharide-binding proteins that can detect differences in glycosylation with some specificity and made a distinction between normal and disease-associated prionic protein successfully [126]. One limit to this approach is the ubiquity of glycosylation; it may not be clear which protein the sugars are actually attached to. For these reasons, false positive results

Table 3a. Oligomeric protein states detected by antibodies

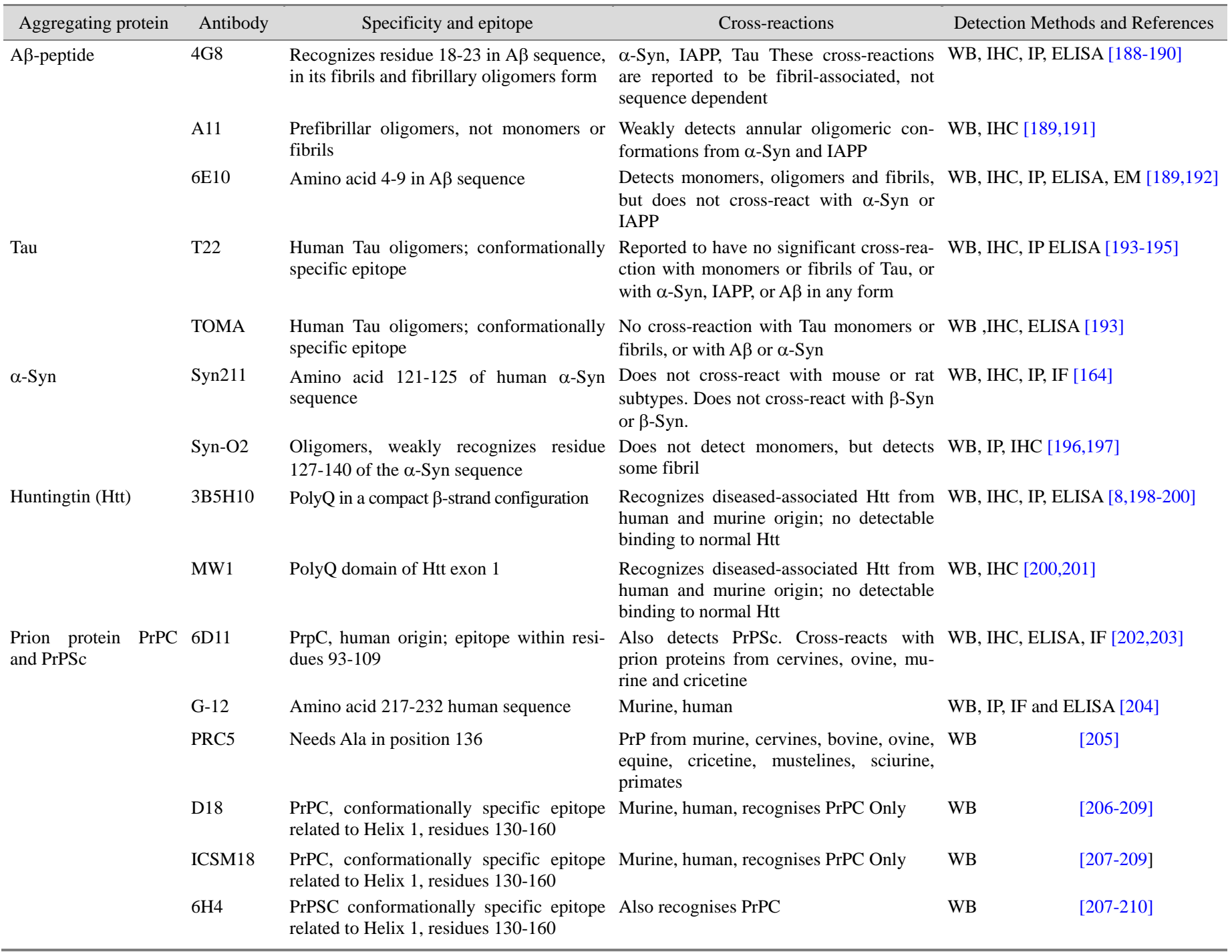


Table 3b. Identification of prion protein glycosylation states

\begin{tabular}{llll}
\hline Prion Protein Glycosylation state & Detection method & Sample type & References and notes \\
$\begin{array}{l}\text { Preferential detection of aglycosyl } \\
\text { and mono-glycosyl }\end{array}$ & $\begin{array}{l}\text { Antibody PRC7; conformationally specific ep- } \\
\text { itope. Residues at position 154, 166, 185 and } \\
197 \text { are involved. }\end{array}$ & $\begin{array}{l}\text { Extract, WB } \\
\text { Lectin proteins affinity for specific glycosyla- } \\
\text { tions }\end{array}$ & $\begin{array}{l}\text { Tissue, IHC } \\
\begin{array}{l}\text { Sialylated and O-glycosidically and 185 are involved [205] } \\
\text { linked glycans }\end{array}\end{array}$ \\
$\begin{array}{l}\text { Glycoproteome of prion protein } \\
\text { variants }\end{array}$ & 708 proteins or protein variants assessed & Murine plasma samples & $\begin{array}{l}\text { Antibodies for PrP (MAB1562 and AB5058) } \\
\text { used to ensure that lectins actually detected prion } \\
\text { proteins [126] } \\
\text { Combined MS-affinity chromatography based } \\
\text { approach [211] }\end{array}$ \\
\hline
\end{tabular}

Table 3c. Identification of oligomeric states by mass spectrometry

\begin{tabular}{|c|c|c|c|c|}
\hline Protein & Oligomeric state detected & Sample type & MS detection method sub-type & Reference \\
\hline$\alpha$-Syn & $\begin{array}{l}\text { Differentiates between oligomers } \\
\text { and monomers }\end{array}$ & Prepared from isolated protein & Hydrogen-Deuterium Exchange, ESI-MS & {$[212]$} \\
\hline$\alpha$-Syn & Monomers and oligomers & Prepared from isolated protein & ESI-ion mobility mass spectrometry & {$[213]$} \\
\hline$\alpha$-Syn & $\begin{array}{l}\text { Differentiates between oligomers } \\
\text { and monomers }\end{array}$ & $\begin{array}{l}\text { Conditioned cell media, similar in } \\
\text { complexity to Cerebrospinal Fluid }\end{array}$ & Combined MS-antibody based approach & {$[214]$} \\
\hline APP, Prion Protein, DJ-1 & Monomers and oligomers & Cerebrospinal Fluid & Tandem MS/MS & {$[215]$} \\
\hline Prion Protein & $\begin{array}{l}\text { Differentiates between PrPC } \\
\text { and PrPSc }\end{array}$ & $\begin{array}{l}\text { Samples prepared from brain } \\
\text { homogenate }\end{array}$ & Quantitative LC-MS/MS & {$[216]$} \\
\hline
\end{tabular}

may be a significant problem unless the detection method can also identify the protein involved clearly. Fortunately, many well-stablished antibodies may help solve this problem (Table $3 a$ ), although extensive glycosylation may sometimes obscure the epitopes involved.

The problems inherent in the types of detection discussed here-low concentration of target protein, subtle differences between correctly and incorrectly folded and aggregated proteins, heterogeneous protein modifications and strong background signals when detecting in a complex biological environment-do not have obvious solutions. However, it seems likely that protein affinity-based techniques (antibodies, lectins) can successfully be combined with instrument-based detection methods, such as mass-spectrometry, fluorescence, and surface plasmon resonance to produce sensitive detection methods able to identify both the aggregation state and modification state of the protein in question. Moreover, there is reason to believe that early detection can give the patient time to benefit from emerging medical technologies such as antibody-based inhibition of oligomer formation [127].

\section{Disclosure}

This study was funded by The Research Council of Norway, The Bergen Medical Research Foundation and the University of Bergen. The authors declare no competing interests. All contributors to the paper have read and agreed on the final version of the manuscript.

\section{Acknowledgements}

We wish to thank Dr. Kristin Viste for reading our manuscript and offering thoughtful insights and comments.

\section{References}

[1] Irwin DJ, Lee VMY, Trojanowski JQ. Parkinson's disease dementia: Convergence of [alpha]-synuclein, tau and amyloid-[beta] pathologies. Nat Rev Neurosci 2013; 14: 626-636.

[2] Petrou M, Dwamena BA, Foerster BR, MacEachern MP, Bohnen NI, Müller MLTM, Albin RL, Frey KA. Amyloid deposition in parkinson's disease and cognitive impairment: A systematic review. Mov Disord 2015; 30: 928-935.

[3] Karran E, Mercken M, Strooper BD. The amyloid cascade hypothesis for alzheimer's disease: An appraisal for the development of therapeutics. Nat Rev Drug Discov 2011; 10: 698-712.

[4] Varadarajan S, Yatin S, Aksenova M, Butterfield DA. Review: Alzheimer's amyloid $\beta$-peptide-associated free radical oxidative stress and neurotoxicity. J Struct Biol 2000; 130: 184-208.

[5] Trevitt CR, Collinge J. A systematic review of prion therapeutics in experimental models. Brain 2006; 129: 2241-2265.

[6] Prusiner SB. Prions. Proc Natl Acad Sci U S A 1998; 95: 13363- 13383.

[7] Morozova OA, Gupta S, Colby DW. Prefibrillar huntingtin oligomers isolated from hd brain potently seed amyloid formation. FEBS Letters 2015; 589: 1897-1903.

[8] Owens GE, New DM, West AP, Jr., Bjorkman PJ. Anti-polyq antibodies recognize a short polyq stretch in both normal and mutant huntingtin exon 1. J Mol Biol 2015; 427: 2507-2519.

[9] Pieri L, Madiona K, Bousset L, Melki R. Fibrillar alphasynuclein and huntingtin exon 1 assemblies are toxic to the cells. Biophys J 2012; 102: 2894-2905.

[10] Kayed R, Sokolov Y, Edmonds B, McIntire TM, Milton SC, Hall JE, Glabe CG. Permeabilization of lipid bilayers is a 
common conformation-dependent activity of soluble amyloid oligomers in protein misfolding diseases. J Biol Chem 2004; 279: 46363-46366.

[11] Selkoe DJ. Alzheimer's disease: Genes, proteins, and therapy. Physiol Rev 2001; 81: 741-766.

[12] Bros P, Vialaret J, Barthelemy N, Delatour V, Gabelle A, Lehmann S, Hirtz C. Antibody-free quantification of seven tau peptides in human csf using targeted mass spectrometry. Front Neurosci 2015; 9: 302.

[13] Polymeropoulos MH, Lavedan C, Leroy E, Ide SE, Dehejia A, Dutra A, Pike B, Root H, Rubenstein J, Boyer R, Stenroos ES, Chandrasekharappa S, Athanassiadou A, Papapetropoulos T, Johnson WG, Lazzarini AM, Duvoisin RC, Di Iorio G, Golbe LI, Nussbaum RL. Mutation in the \&\#x3b1; -synuclein gene indentified in families with parkinson's disease. Science 1997; 276: 2045-2047.

[14] Spillantini MG, Schmidt ML, Lee VMY, Trojanowski JQ, Jakes R, Goedert M. $\alpha$-synuclein in lewy bodies. Nature 1997; 388: 839-840.

[15] Magaki S, Gardner T, Khanlou N, Yong WH, Salmon N, Vinters HV. Brain biopsy in neurologic decline of unknown etiology. Hum Pathol 2015; 46: 499-506.

[16] Haass C, Steiner H. Protofibrils, the unifying toxic molecule of neurodegenerative disorders? Nat Neurosci 2001; 4: 859-860.

[17] Hartmann A, Troadec J-D, Hunot S, Kikly K, Faucheux BA, Mouatt-Prigent A, Ruberg M, Agid Y, Hirsch EC. Caspase-8 is an effector in apoptotic death of dopaminergic neurons in parkinson's disease, but pathway inhibition results in neuronal necrosis. J Neurosci 2001; 21: 2247-2255.

[18] Teng L, Zhao J, Wang F, Ma L, Pei G. A gpcr/secretase complex regulates $\beta$ - and $\gamma$-secretase specificity for a $\beta$ production and contributes to ad pathogenesis. Cell Res 2010; 20: 138-153.

[19] Guardia-Laguarta C, Pera M, Lleo A. \&\#947; -secretase as a therapeutic target in alzheimers disease. Curr Drug Targets 2010; 11: 506-517.

[20] Taylor DM. Inactivation of transmissible degenerative encephalopathy agents: A review. Vet J 2000; 159: 10-17.

[21] Uversky VN, Oldfield CJ, Dunker AK. Intrinsically disordered proteins in human diseases: Introducing the d2 concept. Annu Rev Biophys 2008; 37: 215-246.

[22] Chiti F, Dobson CM. Protein misfolding, functional amyloid, and human disease. Annu Rev Biochem 2006; 75: 333-366.

[23] Gregersen N, Bross P, Vang S, Christensen JH. Protein misfolding and human disease. Annual Review of Genomics and Human Genetics 2006; 7: 103-124.

[24] Naganathan AN, Muñoz V. Scaling of folding times with protein size. J Am Chem Soc 2005; 127: 480-481.

[25] Juraszek J, Bolhuis PG. Rate constant and reaction coordinate of trp-cage folding in explicit water. Biophys $\mathrm{J}$ 2008; 95: 4246-4257.
[26] Leal SS, Botelho HM, Gomes CM. Metal ions as modulators of protein conformation and misfolding in neurodegeneration. Coord Chem Rev 2012; 256: 2253-2270.

[27] Braselmann E, Chaney JL, Clark PL. Folding the proteome. Trends Biochem Sci 2013; 38: 337-344.

[28] Yon JM. Protein folding in the post-genomic era. J Cell Mol Med 2002; 6: 307-327.

[29] Gu Y, Singh A, Bose S, Singh N. Pathogenic mutations in the glycosylphosphatidylinositol signal peptide of prp modulate its topology in neuroblastoma cells. Molecular and Cellular Neuroscience 2008; 37: 647-656.

[30] Ashok A, Hegde RS. Retrotranslocation of prion proteins from the er by preventing gpi signal sequence transamidation. Mol Biol Cell 2008

[31] Stelmashook EV, Isaev NK, Genrikhs EE, Amelkina GA, Khaspekov LG, Skrebitsky VG, Illarioshkin SN. Role of zinc and copper ions in the pathogenetic mechanisms of alzheimer's and parkinson's diseases. Biochemistry (Moscow) 2014; 79: 391-396.

[32] Nedumpully-Govindan P, Yang Y, Andorfer R, Cao W, Ding F. Promotion or inhibition of islet amyloid polypeptide aggregation by zinc coordination depends on its relative concentration. Biochemistry 2015; 54: 7335-7344.

[33] Verasdonck J, Bousset L, Gath J, Melki R, Bockmann A, Meier BH. Further exploration of the conformational space of alpha-synuclein fibrils: Solid-state nmr assignment of a high-ph polymorph. Biomol NMR Assign 2016; 10: 5-12.

[34] Schmidt M, Sachse C, Richter W, Xu C, Fändrich M, Grigorieff N. Comparison of alzheimer $a \beta(1-40)$ and $a \beta(1-42)$ amyloid fibrils reveals similar protofilament structures. Proc Natl Acad Sci 2009; 106: 19813-19818.

[35] Celej MS, Caarls W, Demchenko AP, Jovin TM. A tripleemission fluorescent probe reveals distinctive amyloid fibrillar polymorphism of wild-type alpha-synuclein and its familial parkinson's disease mutants. Biochemistry 2009; 48: 7465-7472.

[36] Bucciantini M, Giannoni E, Chiti F, Baroni F, Formigli L, Zurdo J, Taddei N, Ramponi G, Dobson CM, Stefani M. Inherent toxicity of aggregates implies a common mechanism for protein misfolding diseases. Nature 2002; 416: 507-511.

[37] Diociaiuti M, Gaudiano MC, Malchiodi-Albedi F. The slowly aggregating salmon calcitonin: A useful tool for the study of the amyloid oligomers structure and activity. Int J Mol Sci 2011; $12: 9277$.

[38] Lashuel HA, Petre BM, Wall J, Simon M, Nowak RJ, Walz T, Lansbury Jr PT. $\alpha$-synuclein, especially the parkinson's disease-associated mutants, forms pore-like annular and tubular protofibrils. J Mol Biol 2002; 322: 1089- 1102.

[39] Sokolowski F, Modler AJ, Masuch R, Zirwer D, Baier M, Lutsch G, Moss DA, Gast K, Naumann D. Formation of critical oligomers is a key event during conformational transition of recombinant syrian hamster prion protein. J Biol Chem 2003; 278: 40481-40492. 
[40] Zakharov VV, Mosevitsky MI. Oligomeric structure of brain abundant proteins gap-43 and basp1. J Struct Biol 2010; 170: 470-483.

[41] Luth ES, Stavrovskaya IG, Bartels T, Kristal BS, Selkoe DJ. Soluble, prefibrillar alpha-synuclein oligomers promote complex i-dependent, ca2+-induced mitochondrial dysfunction. J Biol Chem 2014; 289: 21490-21507.

[42] Walsh P, Vanderlee G, Yau J, Campeau J, Sim VL, Yip CM, Sharpe S. The mechanism of membrane disruption by cytotoxic amyloid oligomers formed by prp(106-126) is dependent on bilayer composition. J Biol Chem 2014

[43] Kayed R, Pensalfini A, Margol L, Sokolov Y, Sarsoza F, Head E, Hall J, Glabe C. Annular protofibrils are a structurally and functionally distinct type of amyloid oligomer. J Biol Chem 2009; 284: 4230-4237.

[44] Ding TT, Lee S-J, Rochet J-C, Lansbury PT. Annular $\alpha$-synuclein protofibrils are produced when spherical protofibrils are incubated in solution or bound to brain-derived membranes†. Biochemistry 2002; 41: 10209-10217.

[45] Stöckl M, Fischer P, Wanker E, Herrmann A. $\alpha$-synuclein selectively binds to anionic phospholipids embedded in liquid-disordered domains. J Mol Biol 2008; 375: 1394-1404.

[46] van Rooijen BD, Claessens MMAE, Subramaniam V. Lipid bilayer disruption by oligomeric $\alpha$-synuclein depends on bilayer charge and accessibility of the hydrophobic core. BBA-Biomembranes 2009; 1788: 1271-1278.

[47] Halskau O, Muga A, Martinez A. Linking new paradigms in protein chemistry to reversible membrane-protein interactions. Curr Protein Pept Sci 2009; 10: 339-359.

[48] Amtul Z, Uhrig M, Supino R, Beyreuther K. Phospholipids and a phospholipid-rich diet alter the in vitro amyloid-beta peptide levels and amyloid-beta 42/40 ratios. Neurosci Lett 2010; 481: 73-77.

[49] Gellermann GP, Appel TR, Tannert A, Radestock A, Hortschansky P, Schroeckh V, Leisner C, Lutkepohl T, Shtrasburg S, Rocken C, Pras M, Linke RP, Diekmann S, Fandrich M. Raft lipids as common components of human extracellular amyloid fibrils. Proc Natl Acad Sci U S A 2005; 102: 6297- 6302.

[50] Benilova I, Karran E, De Strooper B. The toxic a $\beta$ oligomer and alzheimer's disease: An emperor in need of clothes. Nat Neurosci 2012; 15: 349-357.

[51] Saponetti MS, Grimaldi M, Scrima M, Albonetti C, Nori SL, Cucolo A, Bobba F, D'Ursi AM. Aggregation of a $\beta(25-35)$ on dopc and dopc/dha bilayers: An atomic force microscopy study. Plos One 2014; 9

[52] Kourie JI, Shorthouse AA. Properties of cytotoxic peptide-formed ion channels. Am J Physiol - Cell Physiol 2000; 278: C1063-C1087.

[53] Ehrnhoefer DE, Bieschke J, Boeddrich A, Herbst M, Masino L, Lurz R, Engemann S, Pastore A, Wanker EE. Egcg redirects amyloidogenic polypeptides into unstructured, off-pathway oligomers. Nat Struct Mol Biol 2008; 15: 558-566.

[54] Harroun TA, Bradshaw JP, Ashley RH. Inhibitors can arrest the membrane activity of human islet amyloid polypeptide independently of amyloid formation. FEBS Letters 2001; 507: 200-204.

[55] Brender JR, Heyl DL, Samisetti S, Kotler SA, Osborne JM, Pesaru RR, Ramamoorthy A. Membrane disordering is not sufficient for membrane permeabilization by islet amyloid polypeptide: Studies of iapp(20-29) fragments. Phys Chem Chem Phys 2013; 15: 8908-8915.

[56] Sciacca Michele FM, Milardi D, Messina Grazia ML, Marletta G, Brender Jeffrey R, Ramamoorthy A, La Rosa C. Cations as switches of amyloid-mediated membrane disruption mechanisms: Calcium and iapp. Biophys J 2013; 104: 173-184.

[57] Sciacca MFM, Brender JR, Lee D-K, Ramamoorthy A. Phosphatidylethanolamine enhances amyloid fiber-dependent membrane fragmentation. Biochemistry 2012; 51: 7676-7684.

[58] Hirakura Y, Azimov R, Azimova R, Kagan BL. Polyglutamine-induced ion channels: A possible mechanism for the neurotoxicity of huntington and other cag repeat diseases. J Neuro Sci 2000; 60: 490-494.

[59] Kagan BL, Jang H, Capone R, Teran Arce F, Ramachandran S, Lal R, Nussinov R. Antimicrobial properties of amyloid peptides. Mol Pharm 2012; 9: 708-717.

[60] Lin M-C, Mirzabekov T, Kagan BL. Channel formation by a neurotoxic prion protein fragment. J Biol Chem 1997; 272: 44-47.

[61] Lin H, Bhatia R, Lal R. Amyloid $\beta$ protein forms ion channels: Implications for alzheimer's disease pathophysiology. FASEB J 2001; 15: 2433-2444.

[62] Hirakura Y, Kagan BL. Pore formation by beta-2-microglobulin: A mechanism for the pathogenesis of dialysis associated amyloidosis. Amyloid 2001; 8: 94-100.

[63] Hirakura Y, Carreras I, Sipe JD, Kagan BL. Channel formation by serum amyloid a: A potential mechanism for amyloid pathogenesis and host defense. Amyloid 2002; 9: 13-23.

[64] Demuro A, Mina E, Kayed R, Milton SC, Parker I, Glabe CG. Calcium dysregulation and membrane disruption as a ubiquitous neurotoxic mechanism of soluble amyloid oligomers. J Biol Chem 2005; 280: 17294-17300.

[65] Dante S, Hauss T, Brandt A, Dencher NA. Membrane fusogenic activity of the alzheimer's peptide a $\beta(1-42)$ demonstrated by small-angle neutron scattering. J Mol Biol 2008; 376: 393-404.

[66] Sokolov Y, Kozak JA, Kayed R, Chanturiya A, Glabe C, Hall JE. Soluble amyloid oligomers increase bilayer conductance by altering dielectric structure.J Gen Physiol 2006; 128: 637-647.

[67] Simons K, Ikonen E. Functional rafts in cell membranes. Nature 1997; 387: 569.

[68] Sevcsik E, Brameshuber M, Folser M, Weghuber J, Honigmann A, Schutz GJ. Gpi-anchored proteins do not reside 
in ordered domains in the live cell plasma membrane. Nat Commun 2015; 6

[69] Valdes-Gonzalez T, Inagawa J, Ido T. Neuropeptides interact with glycolipid receptors a surface plasmon resonance study. Peptides 2001; 22: 1099-1106.

[70] Mahfoud R, Garmy N, Maresca M, Yahi N, Puigserver A, Fantini J. Identification of a common sphingolipid-binding domain in alzheimer, prion, and hiv-1 proteins. J Biol Chem 2002; 277: 11292-11296.

[71] Hebbar S, Lee E, Manna M, Steinert S, Kumar GS, Wenk M, Wohland T, Kraut R. A fluorescent sphingolipid binding domain peptide probe interacts with sphingolipids and cholesterol-dependent raft domains.J Lip Res 2008; 49: 1077-1089.

[72] Yanagisawa K, Odaka A, Suzuki N, Ihara Y. Gm1 ganglioside-bound amyloid $\beta$-protein $(\mathrm{a} \beta)$ : A possible form of preamyloid in alzheimer's disease. Nat Med 1995; 1: 10621066.

[73] Martinez Z, Zhu M, Han S, Fink AL. Gm1 specifically interacts with $\alpha$-synuclein and inhibits fibrillation $\dagger$. Biochemistry 2007; 46: 1868-1877.

[74] Di Pasquale E, Fantini J, Chahinian H, Maresca M, Taïeb N, Yahi N. Altered ion channel formation by the parkinson's-disease-linked e46k mutant of $\alpha$-synuclein is corrected by gm3 but not by gm1 gangliosides. J Mol Biol 2010; 397: 202-218.

[75] Mattei V, Garofalo T, Misasi R, Circella A, Manganelli V, Lucania G, Pavan A, Sorice M. Prion protein is a component of the multimolecular signaling complex involved in t cell activation. FEBS Letters 2004; 560: 14-18.

[76] Sanghera N, Pinheiro TJT. Binding of prion protein to lipid membranes and implications for prion conversion1. J Mol Biol 2002; 315: 1241-1256.

[77] Jo E, McLaurin J, Yip CM, St. George-Hyslop P, Fraser PE. $\alpha$-synuclein membrane interactions and lipid specificity. J Biol Chem 2000; 275: 34328-34334.

[78] Ramakrishnan M, Jensen PH, Marsh D. $\alpha$-synuclein association with phosphatidylglycerol probed by lipid spin labels $\dagger$. Biochemistry 2003; 42: 12919-12926.

[79] Kubo S-i, Nemani VM, Chalkley RJ, Anthony MD, Hattori N, Mizuno Y, Edwards RH, Fortin DL. A combinatorial code for the interaction of $\alpha$-synuclein with membranes. J Biol Chem 2005; 280: 31664-31672.

[80] Pandit SA, Bostick D, Berkowitz ML. Complexation of phosphatidylcholine lipids with cholesterol. Biophys J 2004; 86: 1345-1356.

[81] Barenholz Y. Sphingomyelin and cholesterol: From membrane biophysics and rafts to potential medical applications; in Quinn P (ed): Membrane dynamics and domains, Springer US, 2004, vol 37, pp 167-215.

[82] Veiga MP, Arrondo JLR, Goñi FM, Alonso A, Marsh D. Interaction of cholesterol with sphingomyelin in mixed membranes containing phosphatidylcholine, studied by spin-label esr and ir spectroscopies. A possible stabilization of gel-phase sphin- golipid domains by cholesterol†. Biochemistry 2001; 40: 2614-2622.

[83] Van Echteld CJA, De Kruijff B, Mandersloot JG, De Gier J. Effects of lysophosphatidylcholines on phosphatidylcholine and phosphatidylcholine/cholesterol liposome systems as revealed by 31p-nmr, electron microscopy and permeability studies. BBA-Biomembranes 1981; 649: 211-220.

[84] Urbina JA, Pekerar S, Le H-b, Patterson J, Montez B, Oldfield E. Molecular order and dynamics of phosphatidylcholine bilayer membranes in the presence of cholesterol, ergosterol and lanosterol: A comparative study using 2h-, 13c- and 31p-nmr spectroscopy. BBA-Biomembranes 1995; 1238: 163-176.

[85] Snyder B, Freire E. Compositional domain structure in phosphatidylcholine-cholesterol and sphingomyelin-cholesterol bilayers. Proc Natl Acad Sci U S A 1980; 77: 4055-4059.

[86] Nyberg L, Duan R-D, Nilsson Å. A mutual inhibitory effect on absorption of sphingomyelin and cholesterol. J Nutr Biochem 2000; 11: 244-249.

[87] McIntosh TJ, Magid AD, Simon SA. Cholesterol modifies the short-range repulsive interactions between phosphatidylcholine membranes. Biochemistry 1989; 28: 17-25.

[88] Li X-M, Ramakrishnan M, Brockman HL, Brown RE, Swamy MJ. N-myristoylated phosphatidylethanolamine: Interfacial behavior and interaction with cholesterol. Langmuir 2002; 18 : 231-238.

[89] Fantini J, Yahi N. Molecular insights into amyloid regulation by membrane cholesterol and sphingolipids: Common mechanisms in neurodegenerative diseases. Expert Rev Mol Med 2010; 12: e27.

[90] Harris JR. In vitro fibrillogenesis of the amyloid beta 1-42 peptide: Cholesterol potentiation and aspirin inhibition. Micron 2002; 33: 609-626.

[91] Arispe N, Doh M. Plasma membrane cholesterol controls the cytotoxicity of alzheimer's disease a $\beta p(1-40)$ and (1-42) peptides. FASEB J 2002; 16: 1526-1536.

[92] Yip CM, Elton EA, Darabie AA, Morrison MR, McLaurin J. Cholesterol, a modulator of membrane-associated a $\beta$-fibrillogenesis illogenesis and neurotoxicity1. J Mol Biol 2001; 311: 723-734.

[93] Hartmann T, Kuchenbecker J, Grimm MOW. Alzheimer's disease: The lipid connection. J Neurochem 2007; 103: 159-170.

[94] Cole SL, Grudzien A, Manhart IO, Kelly BL, Oakley H, Vassar R. Statins cause intracellular accumulation of amyloid precursor protein, beta-secretase-cleaved fragments, and amyloid beta-peptide via an isoprenoid-dependent mechanism. J Biol Chem 2005; 280: 18755-18770.

[95] Bar-On P, Rockenstein E, Adame A, Ho G, Hashimoto M, Masliah E. Effects of the cholesterol-lowering compound methyl- $\beta$-cyclodextrin in models of $\alpha$-synucleinopathy. J Neurochem 2006; 98: 1032-1045.

[96] Bosco DA, Fowler DM, Zhang Q, Nieva J, Powers ET, Wentworth P, Lerner RA, Kelly JW. Elevated levels of oxidized cholesterol metabolites in lewy body disease brains accelerate

DOI: http://dx.doi.org/10.18053/jctres.02.201601.003 
$\alpha$-synuclein fibrilization. Nat Chem Biol 2006; 2: 249- 253.

[97] Chang S, Bray SM, Li Z, Zarnescu DC, He C, Jin P, Warren ST. Identification of small molecules rescuing fragile $\mathrm{x}$ syndrome phenotypes in drosophila. Nat Chem Biol 2008; 4: 256-263.

[98] Hashimoto M, Katakura M, Hossain S, Rahman A, Shimada T, Shido O. Docosahexaenoic acid withstands the abeta(25-35)induced neurotoxicity in sh-sy5y cells. J Nutr Biochem 2011; 22: 22-29.

[99] Hashimoto M, Shahdat HM, Yamashita S, Katakura M, Tanabe Y, Fujiwara H, Gamoh S, Miyazawa T, Arai H, Shimada T, Shido O. Docosahexaenoic acid disrupts in vitro amyloid beta(1-40) fibrillation and concomitantly inhibits amyloid levels in cerebral cortex of alzheimer's disease model rats. J Neurochem 2008; 107: 1634-1646.

[100] Cole GM, Frautschy SA. Docosahexaenoic acid protects from amyloid and dendritic pathology in an alzheimer's disease mouse model. Nutr Health 2006; 18: 249-259.

[101] Rescigno T, Capasso A, Tecce MF. Effect of docosahexaenoic acid on cell cycle pathways in breast cell lines with different transformation degree. J Cell Physiol 2016; 231: 1226-1236.

[102] Kotarek JA, Moss MA. Impact of phospholipid bilayer saturation on amyloid-beta protein aggregation intermediate growth: A quartz crystal microbalance analysis. Anal Biochem 2010; 399: 30-38.

[103] Viola KL, Klein WL. Amyloid beta oligomers in alzheimer's disease pathogenesis, treatment, and diagnosis. Acta Neuropathol 2015; 129: 183-206.

[104] Levine H. Thioflavine-t interaction with synthetic alzheimers-disease beta-amyloid peptides - detection of amyloid aggregation in solution. Prot Sci 1993; 2: 404-410.

[105] Miller DL, Potempska A, Wegiel J, Mehta PD. High-affinity rabbit monoclonal antibodies specific for amyloid peptides amyloid-beta(40) and amyloid-beta(42). J Alzheimers Dis 2011; 23: 293-305.

[106] Johansson LBG, Simon R, Bergstrom G, Eriksson M, Prokop S, Mandenius C-F, Heppner FL, Aslund AKO, Nilsson KPR. An azide functionalized oligothiophene ligand - a versatile tool for multimodal detection of disease associated protein aggregates. Biosens Bioelectron 2015; 63: 204-211.

[107] Nystrom S, Psonka-Antonczyk KM, Ellingsen PG, Johansson LBG, Reitan N, Handrick S, Prokop S, Heppner FL, Wegenast-Braun BM, Jucker M, Lindgren M, Stokke BT, Hammarstrom P, Nilsson KPR. Evidence for age-dependent in vivo conformational rearrangement within a beta amyloid deposits. ACS Chem Biol 2013; 8: 1128-1133.

[108] Klingstedt T, Nilsson KPR. Conjugated polymers for enhanced bioimaging. BBA-General Subjects 2011; 1810: 286-296.

[109] Nyström S, Psonka-Antonczyk KM, Ellingsen PG, Johansson LBG, Reitan N, Handrick S, Prokop S, Heppner FL, Wegenast-Braun BM, Jucker M, Lindgren M, Stokke BT, Hammarström P, Nilsson KPR. Evidence for age-dependent in vivo conformational rearrangement within a $\beta$ amyloid deposits. ACS Chem Biol 2013; 8: 1128-1133.

[110] Klingstedt T, Shirani H, Åslund KOA, Cairns NJ, Sigurdson CJ, Goedert M, Nilsson KPR. The structural basis for optimal performance of oligothiophene-based fluorescent amyloid ligands: Conformational flexibility is essential for spectral assignment of a diversity of protein aggregates. Chem-Euro J 2013; 19: 10179-10192.

[111] Ren W, Xu M, Liang SH, Xiang H, Tang L, Zhang M, Ding D, $\mathrm{Li} \mathrm{X}$, Zhang $\mathrm{H}, \mathrm{Hu}$ Y. Discovery of a novel fluorescent probe for the sensitive detection of beta-amyloid deposits. Biosens Bioelectron 2016; 75: 136-141.

[112] Lehallier B, Essioux L, Gayan J, et al. Combined plasma and cerebrospinal fluid signature for the prediction of midterm progression from mild cognitive impairment to alzheimer disease. JAMA Neurol 2015: 1-10.

[113] David MA, Tayebi M. Detection of protein aggregates in brain and cerebrospinal fluid derived from multiple sclerosis patients. Front Neuro 2014; 5: 251.

[114] Shankar GM, Li S, Mehta TH, Garcia-Munoz A, Shepardson NE, Smith I, Brett FM, Farrell MA, Rowan MJ, Lemere CA, Regan CM, Walsh DM, Sabatini BL, Selkoe DJ. Amyloid-beta protein dimers isolated directly from alzheimer's brains impair synaptic plasticity and memory. Nature Med 2008; 14: 837-842.

[115] Rama EC, Gonzalez-Garcia MB, Costa-Garcia A. Competitive electrochemical immunosensor for amyloid-beta 1-42 detection based on gold nanostructurated screen-printed carbon electrodes. Sens Actuators B-Chem 2014; 201: 567- 571.

[116] Yu YY, Zhang L, Li CL, Sun XY, Tang DQ, Shi GY. A method for evaluating the level of soluble beta-amyloid((1-40/1-42)) in alzheimer's disease based on the binding of gelsolin to beta-amyloid peptides. Angew Chem Int Ed 2014; 53: 12832-12835.

[117] Chen S, Svedendahl M, Antosiewicz TJ, Käll M. Plasmon-enhanced enzyme-linked immunosorbent assay on large arrays of individual particles made by electron beam lithography. ACS Nano 2013; 7: 8824-8832.

[118] Schmidt ME, Chiao P, Klein G, Matthews D, Thurfjell L, Cole PE, Margolin R, Landau S, Foster NL, Mason NS, De Santi S, Suhy J, Koeppe RA, Jagust W, Alzheimer's Dis N. The influence of biological and technical factors on quantitative analysis of amyloid pet: Points to consider and recommendations for controlling variability in longitudinal data. Alzheimers Dem 2015; 11: 1050-1068.

[119] Molinuevo JL, Ripolles P, Simo M, Llado A, Olives J, Balasa M, Antonell A, Rodriguez-Fornells A, Rami L. White matter changes in preclinical alzheimer's disease: A magnetic resonance imaging-diffusion tensor imaging study on cognitively normal older people with positive amyloid beta protein 42 levels. Neurobiol Aging 2014; 35: 2671-2680.

[120] Kantarci K, Schwarz CG, Reid RI, Przybelski SA, Lesnick TG, 
Zuk SM, Senjem ML, Gunter JL, Lowe V, Machulda MM, Knopman DS, Petersen RC, Jack CR. White matter integrity determined with diffusion tensor imaging in older adults without dementia influence of amyloid load and neurodegeneration. Jama Neurol 2014; 71: 1547-1554.

[121] Soares JM, Marques P, Alves V, Sousa N. A hitchhiker's guide to diffusion tensor imaging. Front Neurosci 2013; 7

[122] Cheng KK, Chan PS, Fan S, Kwan SM, Yeung KL, Wang Y-XJ, Chow AHL, Wu EX, Baum L. Curcumin-conjugated magnetic nanoparticles for detecting amyloid plaques in alzheimer's disease mice using magnetic resonance imaging (mri). Biomaterials 2015; 44: 155-172.

[123] Kim JH, Ha TL, Im GH, Yang J, Seo SW, Lee IS, Lee JH. Magnetic resonance imaging of amyloid plaques using hollow manganese oxide nanoparticles conjugated with antibody a beta 1-40 in a transgenic mouse model. Neuroreport 2013; 24: 16-21.

[124] Erba EB. Investigating macromolecular complexes using top-down mass spectrometry. Proteomics 2014; 14: 1259-1270.

[125] Shoemaker GK, van Duijn E, Crawford SE, Uetrecht C, Baclayon M, Roos WH, Wuite GJL, Estes MK, Prasad BVV, Heck AJR. Norwalk virus assembly and stability monitored by mass spectrometry. Mol Cell Proteomics 2010; 9: 1742- 1751.

[126] Zomosa-Signoret V, Mayoral M, Limon D, Espinosa B, Calvillo M, Zenteno E, Martinez V, Guevara J. Sialylated and o-glycosidically linked glycans in prion protein deposits in a case of gerstmann-straussler-scheinker disease. Neuropathol 2011; 31: 162-169.

[127] Lambert MP, Velasco PT, Chang L, Viola KL, Fernandez S, Lacor PN, Khuon D, Gong Y, Bigio EH, Shaw P, De Felice FG, Krafft GA, Klein WL. Monoclonal antibodies that target pathological assemblies of abeta. J Neurochem 2007; 100: 23-35.

[128] Burns A, Iliffe S. Alzheimer's disease. BMJ 2009; 338: b158.

[129] Wenk GL. Neuropathologic changes in alzheimer's disease. J Clin Psychiatry 2003; 64 Suppl 9: 7-10.

[130] Revesz T, Holton JL, Lashley T, Plant G, Frangione B, Rostagno A, Ghiso J. Genetics and molecular pathogenesis of sporadic and hereditary cerebral amyloid angiopathies. Acta Neuropathol 2009; 118: 115-130.

[131] Kalia LV, Lang AE. Parkinson's disease. Lancet 2015; 386: 896-912.

[132] Lei P, Ayton S, Finkelstein DI, Adlard PA, Masters CL, Bush AI. Tau protein: Relevance to parkinson's disease. Int J Biochem Cell Biol 2010; 42: 1775-1778.

[133] Bang J, Spina S, Miller BL. Frontotemporal dementia. Lancet 2015; 386: 1672-1682.

[134] van der Zee J, Van Broeckhoven C. Dementia in 2013: Frontotemporal lobar degeneration-building on breakthroughs. Nat Rev Neurol 2014; 10: 70-72.

[135] Dayalu P, Albin RL. Huntington disease: Pathogenesis and treatment. Neurol Clin 2015; 33: 101-114.

[136] Garringer HJ, Murrell J, D'Adamio L, Ghetti B, Vidal R. Modeling familial british and danish dementia. Brain Struct Funct 2010; 214: 235-244.

[137] Rostagno A, Tomidokoro Y, Lashley T, Ng D, Plant G, Holton J, Frangione B, Revesz T, Ghiso J. Chromosome 13 dementias. Cell Mol Life Sci 2005; 62: 1814-1825.

[138] Herve D, Chabriat H. Cadasil. J Geriatr Psychiatry Neurol 2010; 23: 269-276.

[139] Viswanathan A, Gschwendtner A, Guichard JP, Buffon F, Cumurciuc R, O'Sullivan M, Holtmannspotter M, Pachai C, Bousser MG, Dichgans M, Chabriat H. Lacunar lesions are independently associated with disability and cognitive impairment in cadasil. Neurology 2007; 69: 172-179.

[140] Quinlan RA, Brenner M, Goldman JE, Messing A. Gfap and its role in alexander disease. Exp Cell Res 2007; 313: 20772087.

[141] Yoshida T, Nakagawa M. Clinical aspects and pathology of alexander disease, and morphological and functional alteration of astrocytes induced by gfap mutation. Neuropathol 2012; 32: 440-446.

[142] Miranda E, Lomas DA. Neuroserpin: A serpin to think about. Cell Mol Life Sci 2006; 63: 709-722.

[143] Davis RL, Shrimpton AE, Holohan PD, Bradshaw C, Feiglin D, Collins GH, Sonderegger P, Kinter J, Becker LM, Lacbawan F, Krasnewich D, Muenke M, Lawrence DA, Yerby MS, Shaw CM, Gooptu B, Elliott PR, Finch JT, Carrell RW, Lomas DA. Familial dementia caused by polymerization of mutant neuroserpin. Nature 1999; 401: 376-379.

[144] Imran M, Mahmood S. An overview of human prion diseases. Virol J 2011; 8: 559.

[145] Budka H. Neuropathology of prion diseases. Br Med Bull 2003; 66: 121-130.

[146] Takada LT, Geschwind MD. Prion diseases. Semin Neurol 2013; 33: 348-356.

[147] De Michele G, Pocchiari M, Petraroli R, Manfredi M, Caneve G, Coppola G, Casali C, Sacca F, Piccardo P, Salvatore E, Berardelli A, Orio M, Barbieri F, Ghetti B, Filla A. Variable phenotype in a p102l gerstmann-straussler-scheinker italian family. Can J Neurol Sci 2003; 30: 233-236.

[148] Tateishi J, Brown P, Kitamoto T, Hoque ZM, Roos R, Wollman R, Cervenakova L, Gajdusek DC. First experimental transmission of fatal familial insomnia. Nature 1995; 376: 434-435.

[149] Dickson DW, Rademakers R, Hutton ML. Progressive supranuclear palsy: Pathology and genetics. Brain Pathol 2007; 17: 74-82.

[150] Ling H. Clinical approach to progressive supranuclear palsy. J Mov Disord 2016; 9: 3-13.

[151] Baugh CM, Stamm JM, Riley DO, Gavett BE, Shenton ME, Lin A, Nowinski CJ, Cantu RC, McKee AC, Stern RA. Chronic traumatic encephalopathy: Neurodegeneration following 
repetitive concussive and subconcussive brain trauma. Brain Imaging Behav 2012; 6: 244-254.

[152] Stein TD, Alvarez VE, McKee AC. Chronic traumatic encephalopathy: A spectrum of neuropathological changes following repetitive brain trauma in athletes and military personnel. Alzheimers Res Ther 2014; 6: 4.

[153] Steele JC. Parkinsonism-dementia complex of guam. Mov Disord 2005; 20 Suppl 12: S99-S107.

[154] Halper J, Scheithauer BW, Okazaki H, Laws ER, Jr. Meningio-angiomatosis: A report of six cases with special reference to the occurrence of neurofibrillary tangles. J Neuropathol Exp Neurol 1986; 45: 426-446.

[155] Wiebe S, Munoz DG, Smith S, Lee DH. Meningioangiomatosis. A comprehensive analysis of clinical and laboratory features. Brain 1999; 122: 709-726.

[156] Bennett MJ, Rakheja D. The neuronal ceroid-lipofuscinoses. Dev Disabil Res Rev 2013; 17: 254-259.

[157] Vesa J, Hellsten E, Verkruyse LA, Camp LA, Rapola J, Santavuori P, Hofmann SL, Peltonen L. Mutations in the palmitoyl protein thioesterase gene causing infantile neuronal ceroid lipofuscinosis. Nature 1995; 376: 584-587.

[158] Ferrer I, Santpere G, van Leeuwen FW. Argyrophilic grain disease. Brain 2008; 131: 1416-1432.

[159] Klunk WE, Engler H, Nordberg A, Wang YM, Blomqvist G, Holt DP, Bergstrom M, Savitcheva I, Huang GF, Estrada S, Ausen B, Debnath ML, Barletta J, Price JC, Sandell J, Lopresti BJ, Wall A, Koivisto P, Antoni G, Mathis CA, Langstrom B. Imaging brain amyloid in alzheimer's disease with pittsburgh compound-b. Ann Neurol 2004; 55: 306-319.

[160] Marcus C, Mena E, Subramaniam RM. Brain pet in the diagnosis of alzheimer's disease. Clin Nucl Med 2014; 39: E413-E426.

[161] Hu YY, He SS, Wang XC, Duan QH, Grundke-Iqbal I, Iqbal K, Wang JZ. Levels of nonphosphorylated and phosphorylated tau in cerebrospinal fluid of alzheimer's disease patients - an ultrasensitive bienzyme-substrate-recycle enzyme-linked immunosorbent assay. Am J Pathol 2002; 160: 1269-1278.

[162] Lewczuk P, Esselmann H, Bibl M, Beck G, Maler JM, Otto M, Kornhuber J, Wiltfang L. Tau protein phosphorylated at threonine 181 in csf as a neurochemical biomarker in alzheimer's disease-original data and review of the literature. J Mol Neurosci 2004; 23: 115-122.

[163] Lewczuk P, Kornhuber J. Neurochemical dementia diagnostics in alzheimer's disease: Where are we now and where are we going? Expert Rev Proteomics 2011; 8: 447-458.

[164] Parnetti L, Chiasserini D, Persichetti E, Eusebi P, Varghese S, Qureshi MM, Dardis A, Deganuto M, De Carlo C, Castrioto A, Balducci C, Paciotti S, Tambasco N, Bembi B, Bonanni L, Onofrj M, Rossi A, Beccari T, El-Agnaf O, Calabresi P. Cerebrospinal fluid lysosomal enzymes and alpha-synuclein in parkinson's disease. Mov Disord 2014; 29: 1019-1027.

[165] Itoh N, Arai H, Urakami K, Ishiguro K, Ohno H, Hampel H,
Buerger K, Wiltfang J, Otto M, Kretzschmar H, Moeller HJ, Imagawa M, Kohno H, Nakashima K, Kuzuhara S, Sasaki H, Imahori K. Large-scale, multicenter study of cerebrospinal fluid tau protein phosphorylated at serine 199 for the antemortem diagnosis of alzheimer's disease. Ann Neurol 2001; 50: 150-156.

[166] Hampel H, Buerger K, Kohnken R, Teipel SJ, Zinkowski R, Moeller HJ, Rapoport SI, Davies P. Tracking of alzheimer's disease progression with cerebrospinal fluid tau protein phosphorylated at threonine 231. Ann Neurol 2001; 49: 545-546.

[167] Arai H, Ishiguro K, Ohno H, Moriyama M, Itoh N, Okamura N, Matsui T, Morikawa Y, Horikawa E, Kohno H, Sasaki H, Imahori K. Csf phosphorylated tau protein and mild cognitive impairment: A prospective study. Exp Neurol 2000; 166: 201-203.

[168] Farid K, Hong YT, Aigbirhio FI, Fryer TD, Menon DK, Warburton EA, Baron JC. Early-phase c-11-pib pet in amyloid angiopathy-related symptomatic cerebral hemorrhage: Potential diagnostic value? Plos One 2015; 10

[169] Johnson KA, Gregas M, Becker JA, Kinnecom C, Salat DH, Moran EK, Smith EE, Rosand J, Rentz DM, Klunk WE, Mathis CA, Price JC, DeKosky ST, Fischman AJ, Greenberg SM. Imaging of amyloid burden and distribution in cerebral amyloid angiopathy. Ann Neurol 2007; 62: 229-234.

[170] Greenberg SM, Grabowski T, Gurol ME, Skehan ME, Nandigam RNK, Becker JA, Garcia-Alloza M, Prada C, Frosch MP, Rosand J, Viswanathan A, Smith EE, Johnson KA. Detection of isolated cerebrovascular beta-amyloid with pittsburgh compound b. Ann Neurol 2008; 64: 587-591.

[171] Kuusisto E, Parkkinen L, Alafuzoff I. Morphogenesis of lewy bodies: Dissimilar incorporation of alpha-synuclein, ubiquitin, and p62. J Neuropathol Exp Neurol 2003; 62: 1241-1253.

[172] Huebinger S, Bannach O, Funke SA, Willbold D, Birkmann E. Detection of alpha-synuclein aggregates by fluorescence microscopy. Rejuvenation Res 2012; 15: 213-216.

[173] Cook NP, Kilpatrick K, Segatori L, Marti AA. Detection of alpha-synuclein amyloidogenic aggregates in vitro and in cells using light-switching dipyridophenazine ruthenium(ii) complexes. J Am Chem Soc 2012; 134: 20776-20782.

[174] Thirunavukkuarasu S, Jares-Erijman EA, Jovin TM. Multiparametric fluorescence detection of early stages in the amyloid protein aggregation of pyrene-labeled alpha-synuclein. J Mol Biol 2008; 378: 1064-1073.

[175] El-Agnaf OMA, Salem SA, Paleologou KE, Curran MD, Gibson MJ, Court JA, Schlossmacher MG, Allsop D. Detection of oligomeric forms of alpha-synuclein protein in human plasma as a potential biomarker for parkinson's disease. FASEB J 2006; 20: 419-425.

[176] Wang XM, Yu S, Li FF, Feng T. Detection of alpha-synuclein oligomers in red blood cells as a potential biomarker of parkinson's disease. Neurosci Letters 2015; 599: 115-119.

[177] Kassubek J, Juengling FD, Kioschies T, Henkel K, Karitzky J, 
Kramer B, Ecker D, Andrich J, Saft C, Kraus P, Aschoff AJ, Ludolph AC, Landwehrmeyer GB. Topography of cerebral atrophy in early huntington's disease: A voxel based morphometric mri study. J Neurol Neurosurg Psychiatry 2004; 75: 213-220.

[178] O'Keeffe GC, Michell AW, Barker RA. Biomarkers in huntington's and parkinson's disease. Biomarkers in Brain Disease 2009; 1180: 97-110.

[179] Ridha BH, Anderson VM, Barnes J, Boyes RG, Price SL, Rossor MN, Whitwell JL, Jenkins L, Black RS, Grundman M, Fox NC. Volumetric mri and cognitive measures in alzheimer disease - comparison of markers of progression. J Neurol 2008; 255: 567-574.

[180] Edgeworth JA, Farmer M, Sicilia A, Tavares P, Beck J, Campbell T, Lowe J, Mead S, Rudge P, Collinge J, Jackson GS. Detection of prion infection in variant creutzfeldt-jakob disease: A blood-based assay. Lancet 2011; 377: 487-493.

[181] Sawyer EB, Edgeworth JA, Thomas C, Collinge J, Jackson GS. Preclinical detection of infectivity and disease-specific prp in blood throughout the incubation period of prion disease. Sci Rep 2015; 5

[182] Lacroux C, Comoy E, Moudjou M, Perret-Liaudet A, Lugan S, Litaise C, Simmons H, Jas-Duval C, Lantier I, Beringue V, Groschup M, Fichet G, Costes P, Streichenberger N, Lantier F, Deslys JP, Vilette D, Andreoletti O. Preclinical detection of variant cjd and bse prions in blood. Plos Pathogens 2014; 10

[183] Safar JG, Geschwind MD, Deering C, Didorenko S, Sattavat M, Sanchez H, Serban A, Vey M, Baron H, Giles K, Miller BL, DeArmond SJ, Prusiner SB. Diagnosis of human prion disease. Proc Natl Acad Sci U S A 2005; 102: 3501-3506.

[184] Nicholson EM. Detection of the disease-associated form of the prion protein in biological samples. Bioanalysis 2015; 7: 253-261.

[185] Torres M, Cartier L, Matamala JM, Hernandez N, Woehlbier U, Hetz C. Altered prion protein expression pattern in csf as a biomarker for creutzfeldt-jakob disease. Plos One 2012; 7

[186] Furukawa H, Doh-ura K, Okuwaki R, Shirabe S, Yamamoto K, Udono H, Ito T, Katamine S, Niwa M. A pitfall in diagnosis of human prion diseases using detection of protease-resistant prion protein in urine - contamination with bacterial outer membrane proteins. J Biol Chem 2004; 279: 23661-23667.

[187] Notari S, Qing LT, Pocchiari M, Dagdanova A, Hatcher K, Dogterom A, Groisman JF, Lumholtz IB, Puopolo M, Lasmezas C, Chen SG, Kong QZ, Gambetti P. Assessing prion infectivity of human urine in sporadic creutzfeldt-jakob disease. Emerg Infect Dis 2012; 18: 21-28.

[188] Oddo S, Billings L, Kesslak JP, Cribbs DH, LaFerla FM. Abeta immunotherapy leads to clearance of early, but not late, hyperphosphorylated tau aggregates via the proteasome. Neuron 2004; 43: 321-332.

[189] Kayed R, Head E, Sarsoza F, Saing T, Cotman CW, Necula M, Margol L, Wu J, Breydo L, Thompson JL, Rasool S, Gurlo T,
Butler P, Glabe CG. Fibril specific, conformation dependent antibodies recognize a generic epitope common to amyloid fibrils and fibrillar oligomers that is absent in prefibrillar oligomers. Mol Neurodegener 2007; 2: 18.

[190] Hatami A, Monjazeb S, Glabe C. The anti-amyloid-beta monoclonal antibody 4g8 recognizes a generic sequence-independent epitope associated with alpha-synuclein and islet amyloid polypeptide amyloid fibrils. J Alzheimers Dis 2015; 50: 517525.

[191] Hatami A, Albay R, 3rd, Monjazeb S, Milton S, Glabe C. Monoclonal antibodies against abeta42 fibrils distinguish multiple aggregation state polymorphisms in vitro and in alzheimer disease brain. J Biol Chem 2014; 289: 32131-32143.

[192] Gowert NS, Donner L, Chatterjee M, Eisele YS, Towhid ST, Munzer P, Walker B, Ogorek I, Borst O, Grandoch M, Schaller M, Fischer JW, Gawaz M, Weggen S, Lang F, Jucker M, Elvers $\mathrm{M}$. Blood platelets in the progression of alzheimer's disease. PLoS One 2014; 9: e90523.

[193] Castillo-Carranza DL, Sengupta U, Guerrero-Munoz MJ, Lasagna-Reeves CA, Gerson JE, Singh G, Estes DM, Barrett AD, Dineley KT, Jackson GR, Kayed R. Passive immunization with tau oligomer monoclonal antibody reverses tauopathy phenotypes without affecting hyperphosphorylated neurofibrillary tangles. J Neurosci 2014; 34: 4260-4272.

[194] Lasagna-Reeves CA, Castillo-Carranza DL, Sengupta U, Sarmiento J, Troncoso J, Jackson GR, Kayed R. Identification of oligomers at early stages of tau aggregation in alzheimer's disease. FASEB J 2012; 26: 1946-1959.

[195] Wu JW, Herman M, Liu L, Simoes S, Acker CM, Figueroa H, Steinberg JI, Margittai M, Kayed R, Zurzolo C, Di Paolo G, Duff KE. Small misfolded tau species are internalized via bulk endocytosis and anterogradely and retrogradely transported in neurons. J Biol Chem 2013; 288: 1856-1870.

[196] Majbour NK, Vaikath NN, van Dijk KD, Ardah MT, Varghese S, Vesterager LB, Montezinho LP, Poole S, Safieh-Garabedian B, Tokuda T, Teunissen CE, Berendse HW, van de Berg WD, El-Agnaf OM. Oligomeric and phosphorylated alpha-synuclein as potential csf biomarkers for parkinson's disease. Mol Neurodegener 2016; 11: 7.

[197] Vaikath NN, Majbour NK, Paleologou KE, Ardah MT, van Dam E, van de Berg WD, Forrest SL, Parkkinen L, Gai WP, Hattori N, Takanashi M, Lee SJ, Mann DM, Imai Y, Halliday GM, Li JY, El-Agnaf OM. Generation and characterization of novel conformation-specific monoclonal antibodies for alpha-synuclein pathology. Neurobiol Dis 2015; 79: 81-99.

[198] Peters-Libeu C, Miller J, Rutenber E, Newhouse Y, Krishnan P, Cheung K, Hatters D, Brooks E, Widjaja K, Tran T, Mitra S, Arrasate M, Mosquera LA, Taylor D, Weisgraber KH, Finkbeiner S. Disease-associated polyglutamine stretches in monomeric huntingtin adopt a compact structure. J Mol Biol 2012; 421: 587-600.

[199] Nucifora LG, Burke KA, Feng X, Arbez N, Zhu S, Miller J, 
Yang G, Ratovitski T, Delannoy M, Muchowski PJ, Finkbeiner S, Legleiter J, Ross CA, Poirier MA. Identification of novel potentially toxic oligomers formed in vitro from mammalian-derived expanded huntingtin exon-1 protein. J Biol Chem 2012; 287: 16017-16028.

[200] Legleiter J, Lotz GP, Miller J, Ko J, Ng C, Williams GL, Finkbeiner S, Patterson PH, Muchowski PJ. Monoclonal antibodies recognize distinct conformational epitopes formed by polyglutamine in a mutant huntingtin fragment. J Biol Chem 2009; 284: 21647-21658.

[201] Ko J, Ou S, Patterson PH. New anti-huntingtin monoclonal antibodies: Implications for huntingtin conformation and its binding proteins. Brain Res Bull 2001; 56: 319-329.

[202] Shiga Y, Miyazawa K, Sato S, Fukushima R, Shibuya S, Sato Y, Konno H, Doh-ura K, Mugikura S, Tamura H, Higano S, Takahashi S, Itoyama Y. Diffusion-weighted mri abnormalities as an early diagnostic marker for creutzfeldt-jakob disease. Neurology 2004; 63: 443-449.

[203] Wang J, Zhang BY, Zhang J, Xiao K, Chen LN, Wang H, Sun J, Shi Q, Dong XP. Treatment of smb-s15 cells with resveratrol efficiently removes the prp accumulation in vitro and prion infectivity in vivo. Mol Neurobiol 2015

[204] Caughey B, Raymond GJ, Priola SA, Kocisko DA, Race RE, Bessen RA, Lansbury PT, Jr., Chesebro B. Methods for studying prion protein (prp) metabolism and the formation of protease-resistant prp in cell culture and cell-free systems. An update. Mol Biotechnol 1999; 13: 45-55.

[205] Kang HE, Weng CC, Saijo E, Saylor V, Bian J, Kim S, Ramos L, Angers R, Langenfeld K, Khaychuk V, Calvi C, Bartz J, Hunter N, Telling GC. Characterization of conformation-dependent prion protein epitopes. J Biol Chem 2012; 287: 3721937232.

[206] Beringue V, Vilette D, Mallinson G, Archer F, Kaisar M, Tayebi M, Jackson GS, Clarke AR, Laude H, Collinge J, Hawke S. Prpsc binding antibodies are potent inhibitors of prion replication in cell lines. J Biol Chem 2004; 279: 3967139676.

[207] Doolan KM, Colby DW. Conformation-dependent epitopes recognized by prion protein antibodies probed using mutational scanning and deep sequencing. J Mol Biol 2015; 427:
328-340.

[208] Enari M, Flechsig E, Weissmann C. Scrapie prion protein accumulation by scrapie-infected neuroblastoma cells abrogated by exposure to a prion protein antibody. Proc Natl Acad Sci U S A 2001; 98: 9295-9299.

[209] Peretz D, Williamson RA, Kaneko K, Vergara J, Leclerc E, Schmitt-Ulms G, Mehlhorn IR, Legname G, Wormald MR, Rudd PM, Dwek RA, Burton DR, Prusiner SB. Antibodies inhibit prion propagation and clear cell cultures of prion infectivity. Nature 2001; 412: 739-743.

[210] Wiseman FK, Cancellotti E, Piccardo P, Iremonger K, Boyle A, Brown D, Ironside JW, Manson JC, Diack AB. The glycosylation status of prpc is a key factor in determining transmissible spongiform encephalopathy transmission between species. J Virol 2015; 89: 4738-4747.

[211] Wei X, Herbst A, Ma D, Aiken J, Li L. A quantitative proteomic approach to prion disease biomarker research: Delving into the glycoproteome. J Proteome Res 2011; 10: 2687-2702.

[212] Mysling S, Betzer C, Jensen PH, Jorgensen TJ. Characterizing the dynamics of alpha-synuclein oligomers using hydrogen/deuterium exchange monitored by mass spectrometry. Biochemistry 2013; 52: 9097-9103.

[213] Illes-Toth E, Ramos MR, Cappai R, Dalton C, Smith DP. Distinct higher-order alpha-synuclein oligomers induce intracellular aggregation. Biochem J 2015; 468: 485-493.

[214] Emmanouilidou E, Melachroinou K, Roumeliotis T, Garbis SD, Ntzouni M, Margaritis LH, Stefanis L, Vekrellis K. Cell-produced alpha-synuclein is secreted in a calcium-dependent manner by exosomes and impacts neuronal survival. J Neurosci 2010; 30: 6838-6851.

[215] Chiasserini D, van Weering JR, Piersma SR, Pham TV, Malekzadeh A, Teunissen CE, de Wit H, Jimenez CR. Proteomic analysis of cerebrospinal fluid extracellular vesicles: A comprehensive dataset. J Proteomics 2014; 106: 191-204.

[216] Silva CJ, Erickson-Beltran ML, Dynin IC. Covalent surface modification of prions: A mass spectrometry-based means of detecting distinctive structural features of prion strains. Biochemistry 2016; 55: 894-902. 